
tiempos de pandemia

\title{
How to Teach Online? Recommendations for the assessment of online exams with University students in the USA in times of pandemic
}

Juan Rivera-Mata. University of Maryland Global Campus (UMGC) Maryland, USA. jivera@leadingamerica.us

\section{RESUMEN.}

Evaluamos 350 estudiantes de negocios de una Universidad de EE.UU., comparando notas en exámenes online y presencial, diferencias en tipo de estudiante y clase y posible impacto de copiar. Tras un estudio básico estadístico (T-Student y correlaciones) encontramos que diferencias en tipo de estudiante y clase son más relevantes que en notas en exámenes online respecto a presenciales. Estos resultados están en línea con la literatura existente y no esperamos que se copie más en los exámenes online que en los presenciales. Justificamos esto ante la realidad, ampliamente documentada, de que el copiar es una realidad ampliamente presente de forma previa a la pandemia en múltiples países; $50 \%-85 \%$ de los estudiantes universitarios en EE.UU. y otros países reconocen que han copiado al menos una vez. Copiar no es un problema específico de los exámenes online. Enseñanza y exámenes online traen nuevos retos y oportunidades. Recomendamos re-evaluar los métodos pedagógicos y usar más evaluaciones continuadas. Códigos de conducta, algoritmos de identificación de copias, analítica de datos de los sistemas de gestión del aprendizaje para las evaluaciones y los sistemas online de detección de copiar disponibles para revisar exámenes online (Turnitin y similares) reducen la posibilidad de copiar. Ayudemos a los estudiantes a comprender la importancia del aprender sobre las notas. Nosotros debemos aprender más rápidamente a enseñar online para estar a su mismo nivel digital. Mientras más cerca estemos de los estudiantes, mejor los evaluaremos y, más importante, contribuiremos más y mejor a su aprendizaje y educación.

\section{PALABRAS CLAVE.}

Online, exámenes, copiar, plagio.

\section{ABSTRACT.}

We evaluated 350 US University Business Students, comparing in-class and online exams to see differences in type of student and class and evaluating possible cheating impact. After basic statistical analysis (T-Student and correlations), we found that differences in grades related to type of students and type of class are more significant that those associated to online with in-class exams. Results are aligned with literature. In accordance with the results of this and previous studies, we do not expect significant higher level of cheating in online

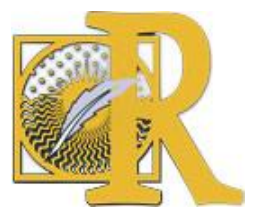

Fecha de recepción: 26-06-2020 Fecha de aceptación: 24-07-2020

Rivera-Mata, J. (2021). ¿Cómo Enseñar Online? Recomendaciones para la evaluación de exámenes online en tiempos de pandemia 
exams versus traditional in-class exams. We justify this based upon the reality, broadly reflected in the literature, that cheating is already quite present, before the coronavirus pandemic Many countries have $50 \%-85 \%$ of University students reporting cheating at least once. Cheating is not an specific online problem. Teaching online brings new challenges and opportunities. We recommend to re-evaluate pedagogical methods and engage more in continuous evaluations, relaying less in exams. Code of Conducts, the use of cheating detection algorithms, data analytics from the online Learning Management Systems for assessment and cheating checking programs available (Turnitin and others) to review online exams is recommended. We should help students understand the importance of learning over grades. Also faculty should online teaching faster be at the same level than students in technology and digital capabilities; the closer we are with our students the more effective we can assess them and, more important, we can contribute more and better to their learning and education.

\section{KEY WORDS.}

Online, exams, cheating, plagiarism.

\section{Introduction.}

Which sector of the economy do you think is being hardest hit by the Coronavirus? The answer is education (Bloom, 2020). The coronavirus pandemic brought unique challenges to Higher Education. One common approach to mitigate its effect has been shifting to online teaching, with limited technological expertise and experience. The possibility of cheating is a key challenge faced overnight. We will evaluate in this paper the limited bibliography existing regarding this topic and we will try to contribute with our data and analysis to improve our ability to be effective in online teaching and specifically in online testing, clarifying about cheating and making some recommendations.

The level of the problem. At the tertiary level, in China the pandemic affects 30 million learners at 3,000 institutions, many of which have responded by rushing to develop and launch mandatory online classes ((Yang, et al., 2020). In the USA, the approximately 19 million undergraduate and graduate students had to go through online testing. In 28 European Countries, most of the aprox. 19.8 Million tertiary students also had to test online. (Eurostat. 2020). China, Europe and USA already have close to 70 million students; most of them going for their first time for online testing in 2020.

Additionally, the US the College Board made the unprecedented decision in May 2020 to administer all approximately 5.1 Million 2020 AP exams digitally. However, the convenient yet abrupt pivot to an online format has resulted in all AP exams will be open-book and opennote. (Sorensen, 2020). Additionally, A record 2.115 million people applied for the yearly Chinese national service exam in 2016 . They competed for 27,000 government posts, with a peak of 10,000 candidates running for a single job (Giustolisi, 2018). We have to expect all those people also had to take online testing in 2020.

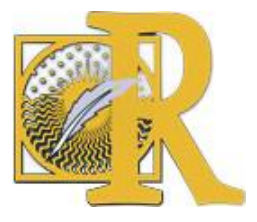

Fecha de recepción: 26-06-2020 Fecha de aceptación: 24-07-2020

Rivera-Mata, J. (2021). ¿Cómo Enseñar Online? Recomendaciones para la evaluación de exámenes online en tiempos de pandemia 


\subsection{Online testing.}

Although this seems to be a unexpected change, the trend to distance learning and online testing has been dramatic during the last years. The Babson Survey Research Group, revealed distance student enrollments increased for fourteenth straight year in 2016. That represented a gain of over $30 \%$ of University students taking at least one distance education course. In the USA, in 2018, 31.6 percent of all students were taking at least one distance education course (of a total of $6,359,121$ students). Distance students are fairly evenly split between those who take both distance and non-distance courses (3,356,041 students) and those who take exclusively distance courses $(3,003,080)$ (Seaman et al., 2018).

The assistance of computers is becoming of critical importance for exams such that the main procedures of modern exams are carried out electronically. For example, Coursera, one of the most popular Massive Online Open Courses (MOOC), allows remote testing. Also, the first step to becoming a permanent employee in one of the European Union agencies is to take a computer-based exam.

In an University study (Spivey \& Mcmillan, 2014) conducted in USA, data was collected through tracking technology usage and grades of 174 students; some students being taught and assessed primarily through online learning platforms while others assessed through traditional pen and paper tests. No significant difference was seen in terms of performance or effort in students taking online exams. The study supports the use of online assessments on the premise that they do not adversely influence student's grades (Spivey \& Mcmillan, 2014). In another perspective provided by a principal in an elementary school in Georgia, the experience of transitioning to online assessment has been reflected upon (Ogletree et al., 2014). While literature shows that the mode of assessment should not affect the scores of students, there has been concern about the comparability of identical tests taken in different formats. The level of student preparedness for the mode of test they take along with the quality of test ultimately influences their grades (Gewertz, 2013). The school administered three tests within nine months to provide practice to students and teachers. Spare back-up devices were allocated in case of device failures, however slow login and delayed loading of test remained an issue which potentially impacted student engagement and possibly grades. It was seen that the results of the first test were negatively skewed, whereas the grades started stabilizing by the third test. The observation clearly highlighted the need for slow transitioning and ample practice on the online assessment format for inexperienced students and teachers (Ogletree et al, 2014).

A study in Romania explored acceptance of online assessments among medical students using a questionnaire. A total of 240 students from all study years were sampled. Results showed a preference for online assessments rather than oral or pen and paper assessments among these students. However, there was increasing degree of acceptance as students moved into higher year groups, probably as they were more accustomed to the format. This University had been conducting online assessments for seven years which could explain students' confidence in the system (Marius et al. 2016). In another University, online assessments were used as formative assessments before in-class tests. It was observed that students who used online formative assessments prior to in-class tests for practice, scored higher than those students who did not. However, these results were inconsistent and did not

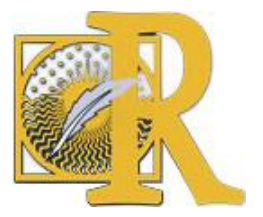

Fecha de recepción: 26-06-2020 Fecha de aceptación: 24-07-2020

Rivera-Mata, J. (2021). ¿Cómo Enseñar Online? Recomendaciones para la evaluación de exámenes online en 
impact performance in cumulative mid-term and final exams. While a clear academic advantage to formative online assessments was not observed, they did not impair grades either (Brown et al., 2015).

\subsection{Cheating.}

University cheating is a universal reality. Already in 1996, one of the first multi-campus studies (McCabe et al.,1996) showed that $52 \%$ of under- graduates claimed to have cheated at least once the previous year. Only a few studies have been conducted on cheating in on-line courses (Grijalva, Nowell, \& Kerkvliet, 2006; Lanier, 2006; Stuber-McEwen, Wiseley, \& Hoggatt, 2009; Szabo \& Underwood, 2003; Underwood \& Szabo, 2006). According to a study of online exams, $45 \%$ of students self-reported negative behaviors, such as lying, cheating, and defiance, during online exams (Russell \& James, 2008), and $73.6 \%$ of the students in the sample believed that it is easier to cheat in an online exam than in a traditional exam (King, Guyette, \& Piotrowski, 2009).

A study (Watson\& Sottile, 2010) of 635 undergraduate and graduate students at a medium sized university focused on student cheating behaviors in both types of classes (on-line and face to face), $32.1 \%$ admitted to having cheated in a live class and $32.7 \%$ admitted to cheating in an on-line class at some point in their higher education coursework. there were no significant differences in the students' admission of cheating for live (face to face) and on-line courses. One possible explanation is that classroom social interaction in live classes plays some part in whether students decide to cheat, which would agree with the findings of StuberMcEwen et al. (2009). Familiarity with fellow students may lessen moral objections to cheating as they work through assignments and assessments together over the course of a school term. The findings indicate that students believe more classmates will cheat in on-line courses than traditional classes are similar to the findings of King et al. (2009).

In Spain, Sureda et al (2009) asked 723 University Students that reported that half of university students polled claimed to have copied while taking an exam at the University in at least one occasion, while a $2.5 \%$ said they had taken an exam supplanting another class-mate at least once. Lupton and Chapman (2002) indicated that $69 \%$ of the students declared they cheated at least once, Chapman and Lupton (2014) reported that $55,4 \%$ of University students in USA declared they cheated in at least one exam in their studies where among student in HongKong it was only $30.2 \%$. In Taiwan, (Shen, 1995) $85 \%$ of the University students reported cheating, where in Japan (Diekhoff et al., 1999) it was of 55.4\%. In Taiwan later (Lyn and Wen, 2004) confirmed a $85 \%$ of 2.608 University students cheated. Bernardi (2004) also reported $66.4 \%$ of students in Holland admitted cheating at least once.

In the review above we have established the level of challenge the pandemic has represented in the University world and how online testing and cheating became the present of a forecasted future. On the other hand, online teaching and cheating has been a progressive reality. So far it seems there a no significant different between in-class and online exam and cheating. We will evaluate now this with our own data.

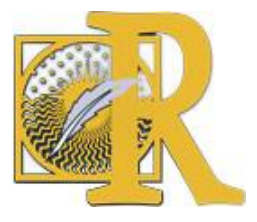

Fecha de recepción: 26-06-2020 Fecha de aceptación: 24-07-2020

Rivera-Mata, J. (2021). ¿Cómo Enseñar Online? Recomendaciones para la evaluación de exámenes online en tiempos de pandemia

International Journal of Educational Research and Innovation (IJERI), 15, 188-202 ISSN: 2386-4303 DOI https://doi.org/10.46661/ijeri.5003 


\section{Material and methods.}

In this study we have evaluated 350 International Business University students of the years 2019 and 2020 belonging to a private mid-size University in the US East Coast. All students have a midterm exam in class and the final exam, with exactly the same format, was conducted online. Each of the exams were $20 \%$ of the total grade and $60 \%$ of the grade came from three different group assignments. All students were instructed before the mid-term and final to prepare some possible questions, to write answers for all of them before the exam. Of the 350 students, 200 were male and 150 females; 143 were from large classes $(60-90$ students) and 207 from regular class size (20-30). Some students had 2 classes per week $(n=253)$ and others only 1 longer class $(n=97)$. Of the total 350 students, 24 were Senior, 118 Junior and 187 Sophomore. 30 students were athletes. We conducted T-student as a basic statistically analysis to find differences among the different groups and defined $<0.05$ as the limit for being statistically significant those differences. Some additional correlation analysis was conducted among some of the variables studied. We chose this statistical methods in order to see differences among the several groups of students and to see the relative importance of each of the exams (in-class and online) with the total grade also among those groups.

\section{Results.}

Table 1. T-Student Final exam (online) versus in-class exam.

\begin{tabular}{|c|c|c|c|}
\hline & In-class & On-line & \\
\hline Mean & 82.50 & 84.50 & $2 \%$ \\
\hline Variance & 223.89 & 102.69 & \\
\hline Observation & 349.0 & 349.0 & \\
\hline Pooled Varia & 163.29 & & \\
\hline Hypothesize & 0.00 & & \\
\hline df & 696.00 & & \\
\hline t Stat & -2.07 & & \\
\hline $\mathrm{P}(\mathrm{T}<=\mathrm{t})$ one- & 0.020 & & \\
\hline
\end{tabular}

On Table 1 above we can see the differences between the grades in the midterm (in-class exam) with the final (online exam). We found only a statistically significant $(p<0.05) 2 \%$ difference, being the online exam the one with better grades. 
Table 2. Correlation in-class, online and total grade.

\begin{tabular}{|l|r|r|r|}
\hline & \multicolumn{1}{|c|}{ In-class } & \multicolumn{1}{c|}{ Online } & Final Grade \\
\hline In-class (20\%) & 1 & & \\
\hline Online (20\%) & 0.116 & 1.0 & \\
\hline Final Grade & 0.376 & $\mathbf{0 . 6 1 9}$ & 1 \\
\hline
\end{tabular}

Additionally, we did a correlation analysis among the 3 grades: in-class midterm (20\% of the total grade), the online final (another $20 \%$ of total grade) and the total grade (with an additional $60 \%$ of grade from group assignments). Table 2 above shows the results. There is a higher correlation between online-exam with the final grade (0.62) that this with the mid-term ( $\mathrm{n}$-class exam (0.38). Also there was a low correlation (0.12) between the two exam grades, mid-term in-class and final online.

Table 3. T-student. Online and Final Grade; sex differences.

\begin{tabular}{|c|c|c|c|c|c|c|c|}
\hline Final-Online & Male & Female & & TOTAL GRADE & MALE & FEMALE & \\
\hline Mean & 82.75 & 86.29 & $4 \%$ & \multirow{8}{*}{\begin{tabular}{|l|} 
Mean \\
Variance \\
Observations \\
Pooled Varian \\
Hypothesized \\
df \\
t Stat \\
$P(T<=t)$ one-tail
\end{tabular}} & 85.86 & 86.290 & $1 \%$ \\
\hline Variance & 146.07 & 85.32 & & & 49.65 & 64.402 & \\
\hline Observation\$ & 200 & 150 & & & 200 & 149 & \\
\hline Pooled Varia & 120.06 & & & & 55.94 & & \\
\hline Hypothesize & 0.00 & & & & 0.00 & & \\
\hline$d f$ & 348.00 & & & & 347.00 & & \\
\hline t Stat & -2.99 & & & & -0.53 & & \\
\hline $\mathrm{P}(\mathrm{T}<=\mathrm{t})$ one-t & 0.001 & & & & 0.300 & & \\
\hline
\end{tabular}

Table 4. Correlation among variables in male and female students.

\begin{tabular}{|c|c|c|c|c|c|c|c|}
\hline FEMALE & In-class Mid & Online Final & Total Grade & MALE & Mid & online & GRADE \\
\hline In-class mid & 1 & & & Mid & 1 & & \\
\hline Online Final & 0.10 & 1 & & Online & 0.12 & 1 & \\
\hline Total Grade & 0.35 & 0.80 & 1 & Grade & 0.40 & 0.50 & 1 \\
\hline
\end{tabular}

Tables 3 and 4 above indicate the differences among male and female students. Women did better $(+4 \%)$ in the final on-line exam than males, being statistically significant $(p<0.01)$, but we could not find any statistically significant differences between male and female in total grades. Looking at the correlation among the 3 variables (mid-term in-class, final online and total grade we find out a higher correlation (0.80) in female students than among male ones (0.50). 
Table 5. T-student Online Exams. Differences Athletes vs rest.

\begin{tabular}{|c|c|c|c|c|c|c|c|}
\hline ONLINE & ATHEL & REST & & GRADE & ATHEL. & REST & \\
\hline \multirow{3}{*}{$\begin{array}{l}\text { Mean } \\
\text { Variance } \\
\text { Observation }\end{array}$} & 83.83 & 84.30 & $-1 \%$ & \multirow{8}{*}{$\begin{array}{l}\text { Mean } \\
\text { Variance } \\
\text { Observation } \\
\text { Pooled Varia } \\
\text { Hypothesize } \\
\text { df } \\
\text { t Stat } \\
P(T<=t) \text { one- }\end{array}$} & 88.45 & 85.84 & $3 \%$ \\
\hline & 128.63 & 122.63 & & & 26.66 & 58.03 & \\
\hline & 30 & 320 & & & 30 & 320 & \\
\hline Pooled Varia & 123.13 & & & & 55.42 & & \\
\hline Hypothesize & 0.00 & & & & 0.00 & & \\
\hline$d f$ & 348.00 & & & & 348.00 & & \\
\hline t Stat & -0.22 & & & & 1.84 & & \\
\hline$P(T<=t)$ one- $t$ & 0.41 & & & & 0.03 & & \\
\hline
\end{tabular}

Table 5 shows differences between normal students and athletes. We could not find any statistically significant differences in online grades, but we found a $3 \%$ lower grades $(p<0.05)$ in the total grades of the athletes.

Table 6. T-Students. Online testing and final grade senior student vs rest.

\begin{tabular}{|c|c|c|c|c|c|c|c|}
\hline TOTAL GRADE & SENIOR & REST & & ONLINE & REST & SENIOR & \\
\hline \multirow{4}{*}{$\begin{array}{l}\text { Mean } \\
\text { Variance } \\
\text { Observations } \\
\text { Pooled Variand }\end{array}$} & 88.88 & 85.81 & $3.6 \%$ & \multirow{8}{*}{\begin{tabular}{|l} 
Mean \\
Variance \\
Observation \\
Pooled Varia \\
Hypothesize \\
df \\
t Stat \\
$P(T<=t)$ one-t
\end{tabular}} & 83.88 & 88.81 & $6 \%$ \\
\hline & 15.27 & 58.24 & & & 129.10 & 26.08 & \\
\hline & 24 & 323 & & & 323 & 27 & \\
\hline & 55.38 & & & & 121.41 & & \\
\hline \multirow{4}{*}{$\begin{array}{l}\text { Hypothesized } \\
\text { df } \\
\text { t Stat } \\
\mathrm{P}(\mathrm{T}<=\mathrm{t}) \text { one-tai }\end{array}$} & 0.00 & & & & 0.00 & & \\
\hline & 345.00 & & & & 348.00 & & \\
\hline & 1.95 & & & & -2.23 & & \\
\hline & 0.03 & & & & 0.01 & & \\
\hline
\end{tabular}

Table 6 above indicates the differences between senior students and the rest. Senior students have a $6 \%$ better grades during the online exams $(p<0.05)$ and also a $3.6 \%$ better total grade in the class $(p<0.05)$.

Table 7. T-Student. Online testing and final grade. Large vs normal class size.

\begin{tabular}{|c|c|c|c|c|c|c|c|}
\hline Total Grade & Large & Normal & & Online Exam & Large & Normal & \\
\hline Mean & 86.67 & 85.65 & $-1 \%$ & \multirow{8}{*}{$\begin{array}{l}\text { Mean } \\
\text { Variance } \\
\text { Observations } \\
\text { Pooled Varian } \\
\text { Hypothesized } \\
\text { df } \\
\text { t Stat } \\
P(T<=t) \text { one-ta }\end{array}$} & 87.70 & 81.89 & $7 \%$ \\
\hline Variance & 34.54 & 70.29 & & & 35.75 & 169.54 & \\
\hline Observation & 143 & 207 & & & 143 & 207 & \\
\hline Pooled Varia & 55.70 & & & & 114.94 & & \\
\hline Hypothesize & 0.00 & & & & 0.00 & & \\
\hline$d f$ & 348.00 & & & & 348.00 & & \\
\hline t Stat & 1.26 & & & & 4.98 & & \\
\hline $\mathrm{P}(\mathrm{T}<=\mathrm{t})$ one- & 0.10 & & & & 0.00 & & \\
\hline
\end{tabular}

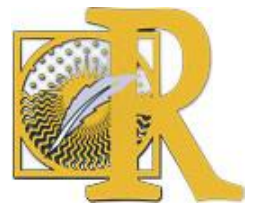


Table 7 above shows the differences between the students in large classes (50-60 students) and those in regular classes (25). Although we could not find significant differences in the total grade, students in large classes did a $7 \%$ better $(p<0.01)$ in the on-line exams than the rest of the students.

Table 8. T-Student. Online testing and final grade. 1-2 classes per week.

\begin{tabular}{|c|c|c|c|c|c|c|c|}
\hline ON-LINE & 1 week & 2 weeks & & Total Grade & 1 Week & 2 Week & \\
\hline Mean & 82.63 & 84.89 & $3 \%$ & \multirow{4}{*}{\begin{tabular}{|l} 
Mean \\
Variance \\
Observations \\
Pooled Variand
\end{tabular}} & 88.17 & 85.26 & $3 \%$ \\
\hline Variance & 173.55 & 102.53 & & & 21.11 & 66.87 & \\
\hline Observations & 97 & 253 & & & 97 & 253 & \\
\hline Pooled Variance & 122.12 & & & & 54.25 & & \\
\hline Hypothesized Me & 0.00 & & & \multirow{4}{*}{$\mid \begin{array}{l}\text { Hypothesized } \\
\text { df } \\
\text { t Stat } \\
P(T<=t) \text { one-tai }\end{array}$} & 0.00 & & \\
\hline df & 348.00 & & & & 348.00 & & \\
\hline t Stat & -1.71 & & & & 3.31 & & \\
\hline $\mathrm{P}(\mathrm{T}<=\mathrm{t})$ one-tail & 0.04 & & & & 0.001 & & \\
\hline
\end{tabular}

Finally, Table 8 above indicates the differences of grades of students having only one (longer) class per week) and those having regular 2 sessions of $75 \mathrm{~m}$ per week. Those students with 2 classes per week have a $3 \%$ better total grade $(p<0.001)$ that those with only one class per week and also better $(+3 \%)$ grades during the online exams $(p<0.05)$.

\section{Discussion.}

The results of this study indicate some minor (2\%) differences in online versus in-class. On the other hand, when some other variables are considered we could find larger differences. Female students have better $(+4 \%)$ grade in online exams but not overall grades, but athletes have better overall grades $(+3 \%)$ and senior students have better grades both in total grade of the course $(+3.6 \%)$ and do significantly better $(+7 \%)$ in online exams versus the rest of the students. Also the type of class has a significant impact in the grade: students in large classes, although having same total grade in the class, have better grades in on-line exams $(+6 \%)$ than students in normal size classes. In a similar way, students having two classes per week have better grades in the total course $(+3 \%)$ and specifically in the online exams $(+3 \%)$.

What can we conclude regarding these results? With the present coronavirus pandemic there is an overall concern regarding the effectiveness of online testing and the possibilities of cheating in those exams. The main factor now considered is on-line versus in-class exams and the concern is about cheating online The results of this study indicates that, although there are some differences in grades in in-class versus online exams, some other variables (type of student and class) seems to be more relevant than the only fact of the being exams in-class or on-line. We cannot make any clear conclusion regarding cheating, but considering pevious studies, the small differences in grade of on-line exams and the relevance of other variables (class type, size, and type of students) we can assume there is no significant additional cheating in online exams versus in-class ones, as the literature suggests. Now we will review the results comparing with some of the limited studies available as per today.

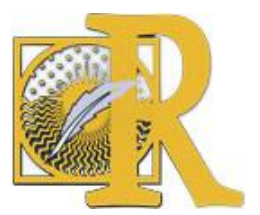

Fecha de recepción: 26-06-2020 Fecha de aceptación: 24-07-2020

Rivera-Mata, J. (2021). ¿Cómo Enseñar Online? Recomendaciones para la evaluación de exámenes online en tiempos de pandemia 


\subsection{Online vs class.}

Hale (2020), in a qualitative study, evaluated 163 College students in Turkey, showing that students report positive attitudes towards online exams and that there was no statistically significant difference in the students' academic achievement in online and traditional exams. The majority of the learners pointed out that online exams were efficient, usable, and reliable while others indicated a level of insufficiency related to exam duration, as well as concerns about potential technical problems that may occur during the implementation of online exams. Understanding the benefits and challenges of online exams will help the institutions in planning their institutional road map. Also Jorczak (2020) suggests that asynchronous peer-to-peer discussion is more effective than traditional classroom lecturediscussion for undergraduate students.

\subsection{Sex.}

Our study shows that female students perform better than males in online exams, but not in the overall course grades. Research has shown that gender may play a role in making ethical decisions. Borkowski and Ugras (1992) found that females expressed greater ethical positions than males when examining and evaluating ethical behaviors. Similarly, Shepard and Hartenian (1991) and Yu et al. (2008) found that females, more so than males, chose an ethical orientation. Ruegger and King (1992) found that age and gender have an impact on business students' development. Their findings suggest that gender is a significant factor related to ethical conduct. Females tend to be more ethical than males in the perception of business ethical situations. Humbarger and DeVaney (2005) not only concluded that female students are more ethical, but also that ethical values increase with a student's age. Stevenson (1999) reported similar conclusions to Humbarger and DeVaney (2005) and Stevenson (1999) noted females reported significantly higher cognitive moral judgment scores than males.

While gender may play a role, research indicates that other external factors may affect student ethical behavior. In line with our own results, students who participated in sports were less ethical than students who did not participate in sports. Stevenson (1999) reported similar conclusions as discussed by Humbarger and DeVaney (2005). Stevenson (1999) noted that females reported significantly higher moral judgment behavior than males. Competitive athletics seem to have a negative effect on the moral reasoning and moral development of athletes. Student athletes who participated in team sports had significantly lower moral behavior when compared to non-athletes or individual sports athletes (Stevenson, 1999).

Females are significantly more likely in online courses to admit to cheating and to have someone give them answers during a test or quiz, but in all other self-reported behaviors, no significant difference existed for gender. It is difficult to determine from the data whether these differences accurately represented cheating behavior or if females were more honest in their survey responses or more ethical in their estimates of what constitutes academically dishonest behavior (Watson and Sottile, 2010).

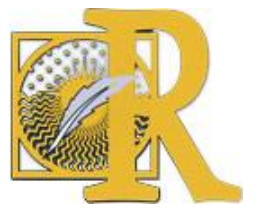

Fecha de recepción: 26-06-2020 Fecha de aceptación: 24-07-2020

Rivera-Mata, J. (2021). ¿Cómo Enseñar Online? Recomendaciones para la evaluación de exámenes online en tiempos de pandemia

International Journal of Educational Research and Innovation (IJERI), 15, 188-202 ISSN: 2386-4303 DOI https://doi.org/10.46661/ijeri.5003 


\subsection{Cheating.}

It is a general problem in US Universities and abroad. A study (Schaffhauser, 2017) suggested that $90 \%$ of University students cheat in the USA at least once. The number of University students who admit to cheating in some form is eye-opening. Donald McCabe (ICal, nd) and the International Center for Academic Integrity between Fall 2002 and Spring 2015 reported that out of 17.000 Graduate students, $43 \%$ reported cheating in tests and assignments and out of 71.300 undergraduate students $68 \%$ confirmed also cheating on test and assignments. In February of 2017 Kessler International released a survey of 300 University students both private and public schools online and bricks and mortar that reported that $86 \%$ of the students claimed they cheated in some way at school (Schaffhauser, 2017). Of those students that cheat they did so in multiple ways: $76 \%$ copied word for word another person's assignment, $79 \%$ copied from the Internet, $42 \%$ purchased custom term papers, essays and thesis online, $28 \%$ indicated that they had a service take their online class and $72 \%$ indicated that they had used their phone, tablet or computer to cheat in class (Schaffhauser, 2017). In the same study, students also felt that instructors cheated by forcing them to buy books written by them to complete the class.

A study by the Pennsylvania State University of 5-6- year-olds showed $56 \%$ cheated even though they knew cheating was not allowed (ETS \& Ad Council, 1999). The same study found students do not believe that they will get caught if they cheat or if they are, they expect the punishment to be minimal.

Among Business Students, another study (King wet al. 2009), evaluating 121 undergraduate students in USA, respondents felt quite liberal in their views of potentially cheating behaviors when there was no test-taking policy set by the course instructor. In addition, $73.6 \%$ of the students in the sample held the perception that it is easier to cheat in an online versus traditional course.

\section{Conclusions.}

When Times Higher Education surveyed (Yang et al., 2020) leaders of prominent global universities in 2018, the 200 respondents - from 45 countries across six continents - were emphatic on one point: online higher education would never match the real thing. Although $63 \%$ expected established, prestigious universities to be offering full degrees online by 2030 , only $24 \%$ thought that the electronic versions would be more popular than traditional campusbased degrees. This study, in line with many others, demonstrates that online cheating is not the problem. The problem, the reality, is the accelerated change to the digital world in Higher Education, in all industries, and also in the work of all and each us, Faculty. The sooner we adapt to the new world the better will be assessing and teaching. More important, this change force us to learn faster to teach better sooner.

\section{Recommendations.}

We have many tools and methods to be effective in the digital teaching world. A more effective way could be to change assessments from objective measures (multiple choice and true-false) to more subjective (essays and research papers) that require more in-depth understanding of a topic and more personal expression. In the case of research papers and essays, faculty

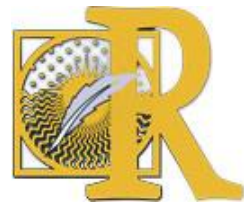

Fecha de recepción: 26-06-2020 Fecha de aceptación: 24-07-2020

Rivera-Mata, J. (2021). ¿Cómo Enseñar Online? Recomendaciones para la evaluación de exámenes online en tiempos de pandemia 
could use programs such as Turnitin to help catch plagiarism. The most significant limitation to changing the assessment type is for subjects that do not lend themselves to subjective assessments, such as mathematics and science, with their use of calculations to get an objective answer. Also the use of automatic online quizzes and tests could be helpful. Finally, the simplest method of all is to reduce the value of the test or quiz compared to other assignments. While this does nothing to discourage or stop sharing of information, it does limit the effect on the student's final grade (Watson \& Sottile, 2010). Liu et al. (2015) also proposed a notarization process, focusing in technological elements.

McCabe and Treviño (1993) advocate the use of Code of Conducts as a tool to avoid or at least limit cheating. A study (Gurung et al., 2002) suggest that modifying an honor code statement is associated with lower levels of self-reported academic dishonesty. Their results take previous work showing modified honor codes are associated with lower levels of student dishonesty (McCabe et al., 2002). Some others (Levitt \& Lin, 2015) proposed having specific algorithms designated to find students copying from each other. Also, to improve the pedagogical and assessment methods used, relying less in exams and focusing more in the process and continuous assessment is necessary (Moreno-Olmedilla, 1999) in order to have a long term improvement in this area. After 4 years of teaching $100 \%$ online classes, using several learning platforms, we recommend to avoid the "copying and pasting" in-class syllabus to online platforms with long $(45-75 \mathrm{~m})$ synchronic and asynchronous lectures and exam-centered, learn the multiple possibilities digital teaching gives us, use the data analytics tools provided and, if needed, the digital programs and webs available (Turnitin and others) to review papers and exams searching for plagiarism. All tools and methods available are useless if we do not learn and learn fast in this digital world, catching up to be at least at the same level of our students.

\section{Limitations and further research.}

This study and review presents multiple limitations. We have very limited experience in online teaching, specially teaching classes $100 \%$ online. The coronavirus pandemic forced us to shift, at the middle of the semester, to online. We need to design classes and syllabus fully online to measure the effectiveness of the different tools, methods and pedagogical methodologies available for digital teaching. This shift, although progressive, has been dramatic in 2020; to use previous studies, reviews and evaluations to evaluate present classes and even to make recommendations for the future clearly has its limitations. On the other hand, the sooner we do reviews and studies, the more prepare we could be to be effective in this new world. Some other limitations are the limited number of students their profile (age, nationality, race and ethnicity, major orientation, economic status, etc.). Also, the exams and grades evaluated in this study are from the years 2019-2020; some before and others during the coronavirus pandemic; it is hard to compare and conclude general learnings for the future. As on-line courses continue to propagate through higher education more research should be competed on academic dishonesty. One possible research idea is the study of the disparity between actual cheating and the perception of dishonesty in on-line courses. Another possible topic is the quantity of cheating by students (Watson \& Sottile, 2010). As we have shifting to the digital world, we should be measuring, evaluating and publishing everything we do in order

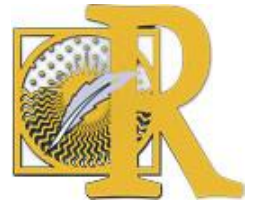

Fecha de recepción: 26-06-2020 Fecha de aceptación: 24-07-2020

Rivera-Mata, J. (2021). ¿Cómo Enseñar Online? Recomendaciones para la evaluación de exámenes online en 
to better and faster prepared in this new world. Now, more than before, we need to evaluate what we do and how we do it, often and quickly. The digital world is a complete new world, but a world with data that allows us more easily to evaluate, conduct research and publish our new learning and findings. More research should be conducted in cheating and plagiarism, comparative student attitudes in classical versus online learning, the effectiveness of different digital pedagogical tools, methodologies. Also, we should continue evaluating the traditional variables of sex/gender, type and background of students, ethnicity, socio-economic level, learning disabilities and others to see the comparative importance and effectiveness of different groups shifting to digital learning. Education should be an instrument for improving social equality; we should not allow that the change to the digital world would make it a tool for increasing inequality. It is in our hands to research, publish and advocate for this not to happen.

\section{References.}

- Bernardi, R. A., Metzger, R. L., Bruno, R. G. S., Hoogkamp, M. A. W., Reyes, L. E. and Barnaby, G. H. (2004). Examining the decision process of students' cheating behavior: An empirical study. Journal of Business Ethics, 50, 397-414.

- Bloom, J. (2020) Coronavirus: Universities fear fall in lucrative overseas students, BBC online, $20^{\text {th }}$ of May. Retrieved from: https://www.bbc.com/news/business-52508018

- Borkowski, S. and Ugras, Y. (1992). The ethical attitudes of students as a function of age, sex, and experience. Journal of Business Ethics, 11 (12) 961-979.

- Brown, G. A., Bice, M. R., Shaw, B. S. and Shaw, I. (2015). Online quizzes promote inconsistent improvements on in-class test performance in introductory anatomy and physiology. Advances in Physiology Education, 39(2), 63-66. https://doi.org/10.1152/advan.00064.2014

- Chapman, K. J. and Lupton, R. A. (2004). Academic dishonesty in a global educational market: A comparison of Hong Kong and American university business students. The International Journal of Educational Management, 18(7), 425-435.

- Diekhoff, G. M.; LaBeff, E., Shinohara, K. and Yasukawa, J. (1999). College cheating in Japan and the United States. Research in Higher Education, 40(3), 43-63.

- Educational Testing Service and Ad Council. (1999). Cheating is a personal foul: The Educational Testing Service and Ad Council campaign to discourage academic cheating. Retrieved from: http://www.glass-castle.com/clients/www-nocheatingorg/adcouncil/research/cheatingfactsheet.html

- Eurostat. (2020). Tertiary Education Statistics. European Union. Retrieved from: https://ec.europa.eu/eurostat/statistics-explained/index.php/Tertiary education statistics

- Gewertz, C. (2013). Transition to online testing sparks concerns. Retrieved from: https://www.edweek.org/ew/articles/2013/10/30/10pencil ep.h33.html

- Giustolisi, R. (2018). Modelling and Verification of Secure Exams, Information Security and Cryptography, Springer International Publishing AG 2018. https://doi.org/10.1007/978-3319-67107-9 1

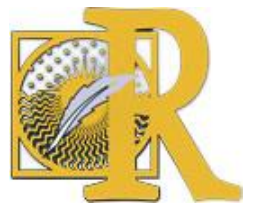

Fecha de recepción: 26-06-2020 Fecha de aceptación: 24-07-2020

Rivera-Mata, J. (2021). ¿Cómo Enseñar Online? Recomendaciones para la evaluación de exámenes online en 
- Graves, L. (2008.). Which Types of Students Cheat Most? Retrieved from: https://www.usnews.com/education/articles/2008/10/03/which-types-of-students-cheat-most

- Grijalva, T., Nowell, C. and Kerkvliet, J. (2006). Academic honesty and online courses. College Student Journal, 40(1), 180-185.

- Gurung, A.R., Wilhelm, T.M. and Fliz, T. (2012) Optimizing Honor Codes for Online Exam Administration, Ethics \& Behavior, 22(2), 158-162. DOI: 10.1080/10508422.2011.641836

- Hale, I. (2020) Providing Online Exams for Online Learners: Does It Really Matter for Them? Education and Information Technologies, 25 (2),1255-1269. http://dx.doi.org.proxyIn.researchport.umd.edu/10.1007/s10639-019-10020-6

- Harwell, D. (2020). Mass school closures in the wake of the coronavirus are driving a new wave of student surveillance. Washington Post, Retrieved from: https://www.washingtonpost.com/technology/2020/04/01/online-proctoring-college-

exams-coronavirus/

- Humbarger, M. and DeVaney, S. (2005). Ethical values in the classroom: How college students responded. Journal of Family and Consumer Sciences, 97 (3) 40-47.

- International Center for Academic Integrity. (n.d.). Integrity: Statistics. Retrieved from: http://www.academicintegrity.org/icai/integrity-3.php

- Jorczak, R. and Dupuis, D.N. (2020) Differences in Classroom versus Online Exam Performance Due to Asynchronous Discussion. Journal of Asynchronous Learning Networks, 18 (2), 1-9. Retrieved from: https://eric.ed.gov/contentdelivery/servlet/ERICServlet?accno=EJ1036271

- King, C., Guyette, R. and Piotrowski, C. (2009). Online exams and cheating: An empirical analysis of business students' views. The Journal of Educators Online, 6(1), 1-11.

- Lanier, M. (2006). Academic integrity and distance learning. Journal of Criminal Justice Education, 17(2), 244-261.

- Lau, J, Yang, B. and Dasgupta, R. (2020) Will the coronavirus make online education go viral? Time Higher Education. Retrieved https://www.timeshighereducation.com/features/will-coronavirus-make-online-education-go-viral

- Levitt, S.D. and Lin, M-J. (2015). Catching Cheating Students, National Bureau of Economic Research. Cambridge, Mass. Retrieved from: http://www.nber.org/papers/w21628

- Lin, Ch.-H y Wen, L.-Y. (2007). Academic dishonesty in higher education: A nationwide study in Taiwán. Higher Education, 54(1), 85-97.

- Liu, I. F., Chen, R. S., and Lu, H. C. (2015). An Exploration into Improving Examinees' Acceptance of Participation in an Online Exam. Educational Technology \& Society, 18 (2), 153-165.

- Lupton, R. A. and Chapman, K. J. (2002). American and Russian University Business students' attitudes, perceptions and tendencies toward cheating. Educational Research, 44(1), 17-29.

- Marius, P., Marius, M., Dan, S., Emilian, C., \& Dana, G. (2016). Medical students' acceptance of online assessment systems. Acta Medica Marisiensis, 62(1), 30-32. Retrieved from: https://doi.org/10.1515/amma-2015-0110

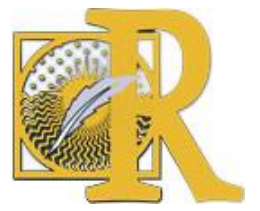

Fecha de recepción: 26-06-2020 Fecha de aceptación: 24-07-2020

Rivera-Mata, J. (2021). ¿Cómo Enseñar Online? Recomendaciones para la evaluación de exámenes online en 
- McCabe, D. L., Treviño, L., and Butterfield, K. D. (1996). The influence of collegiate and corporate codes of conduct on ethics-related behavior in the workplace. Business Ethics Quarterly, 6(4), 461- 476.

- McCabe, D., Treviño, L., and Butterfield, K. (2002). Honor codes and other contextual influences on academic integrity: A replication and extension to modified honor code settings. Research in Higher Education, 43, 357-378.

- Moreno Olmedilla, J. M. (1999). Con trampa y con cartón: el fraude en la educación, 0 cómo la corrupción también se aprende. Cuadernos de Pedagogía, 283, 71-77.

- Ogletree, A., Ogletree, S. and Allen, B. (2014). Transition to online assessments: A personal perspective of meeting common core state standards in an elementary school in Georgia. Georgia educational researcher, 11(1), 170-187. https://doi.org/10.20429/ger.2014.110107

- Ruegger, D. and King, E. (1992). A study of the effect of age and gender upon student business ethics. Journal of Business Ethics, 11 (3) 179-186.

- Russell, S. M. and James, L. R. (2008). Recording lying, cheating, and defiance in an Internet Based Simulated Environment. Computers in Human Behavior, 24(5), 2014-2025.

- Seaman, J.E., Allen, I.E. and Semana, J. (2018) Grade Increase Tracking Distance learning Education in the United States. Babson Survey Research group. Babson College. Retrieved from: http://www.onlinelearningsurvey.com/highered.html .

- Schaffhauser, D. (2017). 9 in 10 Students Admit to Cheating in College, Suspect Faculty Do the Same. Campus Technology. Retrieved from: https:/campustechnology.com/articles/2017/02/23/9-in-10-students-admit-to-cheating-incollege-suspect-faculty-do-the-same.aspx

- Shepard, J. and Hartenian L. (1991). Egoistic and ethical orientations of university students toward work- related decisions. Journal of Business Ethics, 10(4), 303-310.

- Sorensen, T. (2020). 3 Online Testing Considerations for 2019-2020 AP Students, US News. Retrieved from: https://www.usnews.com/education/blogs/college-admissionsplaybook/articles/online-testing-considerations-for-2019-2020-ap-students

- Stevenson, M. J. (1999). Measuring the cognitive moral reasoning of collegiate studentsathletes: The development of the Stevenson-Stoll responsibility questionnaire. Dissertation Abstracts International: Section B: The Sciences and Engineering, 59 (11-B) 6114.

- Spivey, M. F. and Mcmillan, J. J. (2014). Classroom versus online assessment. Journal of Education for Business, 89, 450-456. https://doi.org/10.1080/08832323.2014.937676

- Stuber-McEwen, D., Wiseley, P., and Hoggatt, S. (2009). Point, click, and cheat: Frequency and type of academic dishonesty in the virtual classroom. Online Journal of Distance Learning Administration, 12(3), 1-10.

- Sureda, J., Rubrn, F. and Gli, M. (2009) Academic Dishonest Practices amongst Spanish University Students on Taking Exams and Tests. Estudios sobre Educación, 17, 103-122.

- Underwood, J. \& Szabo, A. (2006). Active Learning in Higher Education, 5(2), 180-199.

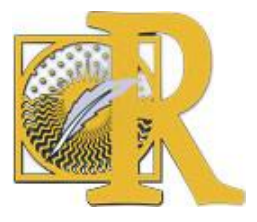

Fecha de recepción: 26-06-2020 Fecha de aceptación: 24-07-2020 Rivera-Mata, J. (2021). ¿Cómo Enseñar Online? Recomendaciones para la evaluación de exámenes online en tiempos de pandemia 
- Watson G. \& Sottile J. (2010) Cheating in the Digital age: Do Students Cheat more in online courses? Online Journal of Distance Learning Administration, 13 (1), 1-12. Retrieved from: https://www.westga.edu/ distance/ojdla/spring131/watson131.html

- Niiya, Y., Ballantyne, R., North, M. \& Crocker, J. (2008). Gender, Contingencies of SelfWorth, and Achievement Goals as Predictors of Academic Cheating in a Controlled Laboratory Setting. Basic and Applied Social Psychology, 30 (1), 76-83. https://doi.org/10.1080/01973530701866656 